\title{
Some 'Facts' Exploded in East Africa
}

Dr David Western in an address to the East African Wildlife Society last year highlighted a few so-called 'facts' that did not stand up to investigation. Ten years ago it was said to be 'obvious' that Amboseli was becoming a dust bowl caused by Masai cattle, tourist vehicles and tree destruction by elephants, and it was also 'well known' that ungulates migrated along a corridor between Amboseli and the Athi Plains. But the familiar Amboseli dust-storms have in fact been going on for thousands of years, said Dr Western, steadily transferring the fine volcanic soil westwards. 'One such storm was followed for some $320 \mathrm{~km}$ into the Serengeti in the vicinity of the Gorr escarpment. Similarly, measurements showed that the amount of erosion resulting from animal trampling and cars was quite insignificant compared with 'natural' wind erosion, and soil analyses showed that much of the bare 'desert' areas is too saline to permit plant growth at all'.

Some striking aerial photographs of Mount Kilimanjaro and a satellite photo on infra-red film which records vegetation in red showed that the life-blood of Amboseli is water from Kilimanjaro, emerging in springs that give rise to swamps which are the only source of permanent water for many miles. Thus, said Dr Western, the swamps serve as a dry season concentration area for grazing mammals which are unable to exploit pastures much more than $15 \mathrm{~km}$ from a drinking place. Regular survey work also revealed that the grazing ungulates using Amboseli have discrete populations which do not mix with others and that the migratory corridor to the Athi Plains did not exist.

\section{Rain That Caused a 'Drought'}

The die-off of the Acacia woodlands was not due to elephants, but the result of exceptionally heavy rains raising a saline water table until it came into contact with the tree roots. The roots were surrounded by a soil solution with a higher osmotic pressure than that in the root cells, with the result that the roots lost water to the soil instead of vice versa, causing death by 'physiological drought'. Partly as a result of less available Acacia foliage, the elephants were forced into the swamps where they opened up the dense sedges,permitting invasion of the swamp by more palatable grass species which were then available for other herbivores.

'The Masai were also found to be exploiting the Amboseli ecosystem in the same manner as the migratory wildebeest and zebra, the main difference being that the Masai cannot break their herds up into really small ones in response to poor grazing conditions, as wild ungulates do, because there is not sufficient man-power for herding many small groups of cattle. One consequence of making Amboseli a national park, from which domestic stock is excluded, is that it will be impossible for the Masai herds ever to build up again to a level capable of providing the sole support of a growing human population in the traditional pastoral manner. The Amboseli Masai are already changing their life-style, some having even become growers of cash crops such as onions.

'Studies of tourists and their vehicles also showed that habitat damage was more apparent than real. Effects on animals are also generally harmless, except in the case of the cheetah which may all too easily be forced away from young cubs.' 